\title{
Razlaga preferenc do okolice in lokacije doma
}

Prispevek temelji na raziskavi, ki je bila izvedena na Danskem in v sklopu katere je naključni vzorec prebivalstva odgovarjal na vprašanja o svojih preferencah do okolice in lokacije svojega doma. Izkazalo se je, da so značilnosti socialnega okolja zelo pomembne in da jih lahko razdelimo v tri ločene skupine: izogibanje socialnim tegobam, dajanje prednosti socialni homogenosti ter bivanje blizu socialne mreže in domačega kraja. Raziskava je pokazala, da ima večina ljudi veliko število podrobnih preferenc, nekateri pa jih imajo zelo malo. To potrjuje starejšo teorijo, da so nekateri ljudje zelo povezani z določenimi kraji z danimi lastnostmi in zato nimajo posebnih želja glede okolice in lokacije doma. Za druge, večinoma mlade in samske, pa je dom samo kraj, na katerem spijo in se spočijejo, medtem ko življenje poteka drugje. Ta skupina ima samo preference do lokacije in le malo specifičnih preferenc do okolice.

Ključne besede: stanovanjske preference, okolica, lokacija, Danska 


\section{Uvod}

V prispevku so predstavljeni izsledki danske raziskave o preferencah do okolice in lokacije doma. Podatki so bili pridobljeni $s$ pomočjo ankete, ki so jo izvedli med naključno izbranimi Danci. Prispevek podaja odgovore na ta vprašanja:

- Katere lastnosti okolice in lokacije doma so najpomembnejše?

- Kako lahko pojasnimo odstopanja v preferencah do teh lastnosti?

- Kako se preference spreminjajo v različnih življenjskih obdobjih?

- Katere so razlike med ljudmi z različnimi preferencami do življenja v mestu ali na podeželju?

O stanovanjskih preferencah in o tem, kako in zakaj se razlikujejo po posameznih skupinah in zemljepisnih območjih, je bilo doslej narejenih malo raziskav. Eden od razlogov je ta, da je stanovanjske preference težko natančno določiti zaradi težav na stanovanjskem trgu, kot tudi zato, ker ljudem pogosto primanjkuje sredstev in zato ne morejo uresničiti svojih preferenc ter živeti v želenem domu in okolici. $Z$ raziskavami o stanovanjskih preferencah so povezana tudi določena metodološka vprašanja, in sicer ali bi bilo bolje preučevati, kje ljudje hočejo živeti ali kje dejansko živijo. Kljub temu je bilo veliko podatkov pridobljenih $\mathrm{z}$ raziskavami o stanovanjskem povpraševanju, razlogih za to, da nekdo ostane na določenem kraju ali se preseli drugam, navezanosti na neki kraj in zadovoljstvu s stanovanjem.

V prvem delu prispevka je pojasnjeno, kaj lahko sklepamo iz raziskav o tem, kaj se ljudem zdi pomembno glede okolice in lokacije doma. Izsledki raziskav ustvarjajo nekoliko zmedeno podobo. Izluščimo lahko štiri glavne vidike: (a) fizično okolje, (b) socialno okolje, (c) dostopnost lokalnih javnih in zasebnih storitev ter (d) lokacija in prevoz v širšem kontekstu. Poleg tega se je izkazalo, da se preference zelo razlikujejo med posamezniki in da so te razlike odvisne predvsem od razlik $\mathrm{v}$ družinskem statusu, življenjskem obdobju, dohodku in drugih virih ter kulturi in življenjskem slogu.

Glavni navdih za pričujočo raziskavo je bila teorija, ki jo je oblikoval Thorklid Ærø (2002) in po kateri imajo ljudje različna kulturna izhodišča, ki določajo, kako močna ali šibka so njihova mnenja o okolici in lokaciji njihovega doma. Med drugim opozarja na dejstvo, da so nekateri ljudje lahko močno navezani na nekatere kraje z določeno okolico, vendar to niso njihove preference. Za druge je dom samo kraj, na katerem spijo in se spočijejo, medtem ko jih okolica pretirano ne zanima. Pričujoča raziskava potrjuje Ærøvo teorijo.

\section{Prejšnje raziskave o pomenu okolice in lokacije doma}

Kaj se ljudem zdi pomembno v njihovem domu in njegovi okolici, lahko ugotovimo z zelo različnimi vrstami raziskav. Tega ni mogoče ugotoviti samo s specifičnimi raziskavami o stanovanjskih preferencah, temveč tudi z raziskavami o tem, kako ljudje uporabljajo svoj dom in kako so navezani nanj. To lahko ugotovimo $s$ preučevanjem vzrokov navezanosti na določen kraj ter (ne)zadovoljstva s stanovanjem in stanovanjskim območjem.

\subsection{Posebne raziskave stanovanjskih preferenc}

Posebne raziskave stanovanjskih preferenc lahko temeljijo na navedenih ali ugotovljenih preferencah, pri katerih gre v resnici za izbiro okolice in lokacije (Timmermans idr., 1994; Floor in Van Kempen, 1997; Coolen in Hoekstra, 2001). Navedene preference se določajo z neposrednim spraševanjem ljudi, kako bi najraje živeli in zakaj. Ugotovljene preference pa se določijo s preučevanjem, kako ljudje dejansko živijo, in lahko veljajo za pred kratkim priseljena gospodinjstva ali vsa gospodinjstva. Pri obeh metodah pa obstajajo določeni metodološki problemi. Pri navedenih preferencah se lahko zgodi, da ljudje ne upoštevajo njihove uresničljivosti. To pomeni, da so lahko velika odstopanja med odgovori gospodinjstev, ki bi morala imeti enake preference, saj imajo nekatera realno predstavo o možnostih na stanovanjskem trgu (in to upoštevajo pri svojem odgovoru), medtem ko je druga nimajo in zato njihove preference niso realne. Druga pogosta težava je ta, da se pri stanovanjskih preferencah po navadi ločeno upošteva veliko različnih vidikov dóma. V resničnem svetu ljudje, ki iščejo hiše, upoštevajo različne kombinacije stanovanjskih značilnosti. Za obvladovanje te kompleksnosti so bile razvite različne metode (Coolen in Hoekstra, 2001).

Tako ločimo med temi preferencami (Floor in Van Kempen, 1997):

- absolutne preference do doma, njegove okolice in lokacije, ki so bistveni pogoji za izbiro doma;

- kompromisne preference, ki jih je mogoče žrtvovati za druge prednosti, in

- relativne preference, ki so pomembne, vendar zaradi njih ne bi zavrnili stanovanja, če ne bi bile izpolnjene.

Težava z metodo ugotovljenih preferenc je ta, da dejanski stanovanjski položaj ne izraža vedno temeljnih preferenc. To pa zato, ker so pomembne realne možnosti na stanovanjskem trgu in gmotno stanje posameznika. Čeprav bi poskusili opredeliti ekonomsko pogojene preference, bi lahko dejanski položaj dajal lažni vtis, saj lahko tržni predpisi in neravnovesja na trgu 
onemogočajo pridobitev optimalnega stanovanja (Skifter Andersen in Bonke, 1980; Timmermans idr., 1994). Poleg tega lahko različne okoliščine, ki ovirajo mobilnost, povzročijo, da družine kljub velikim spremembam stanovanjskih potreb ostanejo v istem domu, ki sčasoma vse bolj odstopa od njihovih preferenc (Skifter Andersen in Bonke, 1980).

$\mathrm{O}$ »povprečnih « preferencah lahko govorimo samo do določene mere, toda ta povprečja se lahko zelo razlikujejo glede na to, kje raziskava poteka, pa tudi med različnimi državami in vrstami urbanih območij. Tom Kauko (2006) je pokazal, da se navedene preference do okolja in lokacije razlikujejo med Finsko in Nizozemsko, mestnimi središči in predmestji ter med večdružinskimi in enodružinskimi hišami. Pri finskih večdružinskih hišah je bila najpomembnejša oddaljenost lokacije do delovnega mesta in storitev, sledili so lokalne storitve, fizično okolje in lokalne socialne razmere. Pri enodružinskih hišah v Helsinkih so najpomembnejše socialne razmere, sledijo lokacija, fizično okolje in lokalne storitve. V nizozemskih predmestjih je bilo najpomembnejše fizično okolje, in sicer pred storitvami, lokacijo in socialnimi dejavniki. $\mathrm{V}$ raziskavi, ki sta jo o navedenih preferencah do značilnosti doma $\mathrm{v}$ nizozemskih mestih Rotterdam in Tilburg izvedla Han Floor in Ronald Van Kempen (1997), je bila velikost stanovanja pogosto navedena kot najpomembnejša značilnost, sledili so vrsta stanovanja, stanovanjski stroški, dvorišče, lokacija in lokalne storitve. Preference do dveh od treh značilnosti so bile označene kot absolutne, kar pomeni, da so morale biti izpolnjene. To se je nanašalo predvsem na velikost stanovanja in stanovanjske stroške, včasih pa tudi na vrsto stavbe in socialno strukturo lokalnega območja. Pri približno 20 \% značilnosti je šlo za kompromisne preference. Večina anketirancev ni upoštevala okoljskih preferenc, zlasti na račun nižjih stanovanjskih stroškov ali zaželene vrste stanovanja.

Ærø $(2002,2006)$ je opravil obsežno raziskavo selitev gospodinjstev v danskem mestu Aarhus. Razlikoval je med značilnostmi doma, oblikami lastništva, značilnostmi stavbe in lokacije in socialno strukturo lokalnega območja. $V$ anketi so se za najpomembnejše izkazale splošne značilnosti dóma, sledili pa sta okolica in lokacija. Med preferencami do lokacije in okolice je bila na prvem mestu bližina zelenih površin, in sicer pred bližino delovnega mesta, neobstojem prometa in hrupa, bližino javnega prevoza, bližino mestnega jedra, ugledom in socialnim statusom območja, videzom ulic, stavb in trgov, zasebnimi storitvami v soseski, pogoji za otroke, duhom skupnosti, javnimi ustanovami, objekti za šport in prosti čas in kulturnimi dejavnostmi. Raziskava je v povezavi s preferencami glede značilnosti sosesk pokazala nekatere splošne razlike med tistimi, ki so se preselili v različne vrste stanovanj. Lastnike so razmere v soseski bolj skrbele kot najemnike. Med preferencami o socialni strukturi prebivalcev soseske so bile najpomembnejše te: (a) visoka stopnja zasebnosti in mir, (b) življenje med ljudmi $s$ podobnimi nazori o obnašanju, (c) življenje blizu prijateljev, (d) življenje blizu ljudi, ki govorijo isti jezik in prihajajo iz istega kulturnega okolja, (e) življenje blizu sorodnikov, (f) življenje blizu drugih družin z otroki, (g) življenje blizu vrstnikov, (h) življenje blizu ljudi z enakim okusom, (i) življenje blizu ljudi s podobno službo ali izobrazbo in (j) življenje blizu ljudi s podobnimi konjički.

\subsection{Raziskave o zadovoljstvu s sosesko}

Pomen različnih značilnosti okolice in lokacije doma je obravnavan tudi v literaturi o zadovoljstvu s sosesko. Te znaćilnosti se različno razvrščajo. Kot je razvidno iz preglednice 1 , so v štirih različnih raziskavah dejavniki razvrščeni v pet komponent.

Ronald John Johnston (1973) komponento fizičnega okolja opisuje kot »neosebno okolje «, ki je sestavljeno predvsem iz fizičnih dejavnikov soseske. Njegova raziskava je pokazala, da preference do soseske temeljijo na treh osnovnih evalvacijskih razsežnostih, ki se ne spreminjajo glede na kraj prebivanja $\mathrm{v}$ mestu. Victoria Basolo in Denise Strong (2002) sta determinante zadovoljstva s sosesko razdelili na posamezne značilnosti prebivalcev in štiri tipe značilnosti soseske. Ene izmed njih so bile »razmere v fizičnem okolju«. Poleg tega so Alison Parkes idr. (2002) svoje spremenljivke razdelili na šest različnih tipov. Enega izmed njih so poimenovali »okoljske značilnosti«, ki so jih določili tako, da so anketirance spraševali o splošnem videzu območja, objektih za prosti čas in hrupu.

Johnston (1973) je lokacije in storitve preučeval glede na lastnosti lokacije soseske $\mathrm{v}$ primerjavi z mestom in njegovimi storitvami. Basolo in Strong (2002) sta to komponento imenovali »lokalne storitve/infrastruktura «. Parkes idr. (2002) so se osredotočili na kakovost javne infrastrukture v soseski, kot so šole, javni prevoz, ulična razsvetljava in podobno, kot tudi na dostopnost infrastrukture v soseski, kot so supermarketi, pošte in manjše trgovine. George Galster idr. (2002) so izvedli analizo glavnih komponent na pokazateljih kakovosti sosesk šestih ameriških mest in opredelili šest dejavnikov, $s$ katerimi so razložili dve tretjini celotne variance. Eden od teh je bil število podjetij in zaposlenih $\mathrm{v}$ soseski.

Johnston je uporabil izraz »medosebno okolje« (ang. interpersonal environment), ki je sestavljeno predvsem iz socialnih lastnosti soseske, medtem ko sta Basolo in Strong (2002) govorili o »socialno-kulturnem okolju « (ang. sociocultural environment). Temu bi lahko rekli tudi »socialno okolje«. Raziskava, ki so jo opravili Parkes idr. (2002), je to komponento razdelila na »pozitivne socialne značilnosti « (prijazni sosedje, duh skupnosti) in »negativne socialne značilnosti « (kriminal in varnost, neprijazni sosedje). V raziskavi, ki so jo 
Preglednica 1: Klasifikacija dejavnikov zadovoljstva s sosesko

\begin{tabular}{|c|c|c|c|c|c|}
\hline Raziskava & Fizično okolje & Lokacija in storitve & Socialno okolje & Stanovanje & Ugled/status \\
\hline Johnston (1973) & "neosebno okolje» & lastnosti lokacije & "medosebno okolje» & & \\
\hline Basolo in Strong (2002) & razmere v fizičnem okolju & $\begin{array}{l}\text { značilnosti lokacije in } \\
\text { storitve/infrastruktura }\end{array}$ & socialno-kulturno okolje & & \\
\hline \multirow[t]{2}{*}{ Galster idr. (2002) } & & podjetja in zaposlitev & $\begin{array}{l}\text { socialne } \\
\text { pomanjkljivosti }\end{array}$ & $\begin{array}{l}\text { vrsta stanovanj } \\
\text { in lastništva }\end{array}$ & prestižnost \\
\hline & & & stopnja kriminala & prazna stanovanja & \\
\hline Parkes idr. (2002) & okoljske značilnosti & $\begin{array}{l}\text { kakovost infrastrukture } \\
\text { v soseski } \\
\text { dostopnost infrastrukture } \\
\text { v soseski }\end{array}$ & $\begin{array}{l}\text { pozitivne socialne } \\
\text { značilnosti } \\
\text { negativne socialne } \\
\text { značilnosti }\end{array}$ & $\begin{array}{l}\text { zadovoljstvo s } \\
\text { stanovanjem }\end{array}$ & \\
\hline
\end{tabular}

opravili Galster idr. (2002), lahko najdemo izraze »socialne pomanjkljivosti« (ang. social disadvantages, na primer delež gospodinjstev, v katerih je ženska glava družine, delež mladoletnih mater, delež prejemnikov socialne pomoči in delež temnopoltih prebivalcev), »kriminal « (stopnja nasilnih kaznivih dejanj) in » prestižnost « (delež prebivalcev z visokošolsko izobrazbo, delež vodstvenih, strokovnih in tehničnih poklicev ter povprečne družinske vrednote).

Značaj lokalnega stanovanjskega trga v soseski je bil pomemben v raziskavi, ki so jo izvedli Galster idr. (2002). Osredotočili so se na vrsto stanovanj in lastništva (delež enodružinskih hiš in stanovalcev, ki so obenem lastniki), prazna stanovanja (delež praznih stanovanj in stanovanj brez najnujnejše napeljave) in zadovoljstvo s stanovanjem. Parkes idr. (2002) so opozorili na povezavo med zadovoljstvom $s$ stanovanjem in zadovoljstvom $s$ sosesko. Veliko raziskav je razkrilo, da sta strah pred kriminalom in pomanjkljiva varnost zelo pomembna dejavnika, ki vplivata na zadovoljstvo s sosesko, saj lahko visoka stopnja kriminala zelo zmanjša sicer visoko zadovoljstvo $s$ sosesko med prebivalci, ki se ne nameravajo preseliti (Skifter Andersen, 2008). Med dejansko stopnjo kriminala in tem, kako prebivalci dojemajo lokalni kriminal, ne moremo vedno vzpostaviti neposredne povezave (Basolo in Strong, 2002). Tako je za zadovoljstvo dojemanje kriminala pomembnejše kot dejanska stopnja kriminala. Kot sta ugotovila Ærø (2006) in Teresa Costa Pinho (2000), občutek varnosti ni povezan samo z opaženim kriminalom, temveč tudi s spori med prebivalci ali skupinami prebivalcev. Ti spori včasih temeljijo na izkušnjah z drugimi stanovalci, ki se ne obnašajo v skladu s splošno sprejetimi normami in pravili obnašanja. To potrjuje, da je v socialno in etnično heterogenih soseskah večja verjetnost, da prebivalci ne bodo zadovoljni s svojo sosesko.

Raziskava Parkes idr. (2002) je pokazala, da je najpomembnejši dejavnik, ki poleg zadovoljstva $s$ stanovanjem pojasnjuje zadovoljstvo s sosesko, fizično stanje (»splošni videz soseske «). Drugi pomembni dejavniki so hrup, prijaznost sosedov, »duh skupnosti « in varnost. Basolo in Strong (2002) sta prav tako ugotovili, da so fizične razmere pomembne, vključno s čistočo in prometom. Ugotovili sta tudi, da imajo socialni stiki zelo velik vpliv na zadovoljstvo. Druge raziskave (Carp idr., 1976; Franscescato idr., 1987) so tudi pokazale, da imajo fizične težave (na primer slabo vzdrževanje, smeti, grafiti, hrup in onesnaženost) in socialni stiki velik vpliv na zadovoljstvo ljudi s sosesko.

\subsection{Raziskave o navezanosti na kraj}

V strokovni literaturi o »navezanosti na kraj « je ta pojav različno poimenovan. Lahko je opredeljen kot »učinkovita vez med ljudmi in kraji ali čustvena povezanost $s$ kraji (Hidalgo in Hernández, 2001) ali » pozitivna čustvena vez, ki se razvije med posamezniki ali skupinami in njihovim okoljem « (Mesch in Manor, 1998). Drugi (na primer Cuba in Hummon, 1993) uporabljajo koncept »identitete kraja « (ang. place identity), ki je razdeljen na dva vidika: izkazovanje, pri katerem ljudje pustijo sled v svojem okolju in mu dajo status in identiteto, ter pripadnost, ki je povezana $s$ čustveno navezanostjo in $\mathrm{z}$ vrednotami, ki so skupne ljudem v soseski.

Carmen Hidalgo in Bernardo Hernández (2001) trdita, da ljudje iščejo kraje, na katerih so se rodili, ali pa poiščejo kraj, ki se jim zdi prijeten in varen ter na katerem se običajno najbolje počutijo. Toda ljudje se navezanosti na svoj kraj ne zavedajo vedno. Pogosto se ne zavedajo svojih vezi s krajem, v katerem živijo, dokler jim ni treba razmišljati o preselitvi. Kraj ima lahko različen pomen za različne ljudi. Navezanost je lahko povezana $\mathrm{z}$ različnimi prostorskimi obsegi, kot so dom, soseska, mesto ali regija. Večina raziskav se je doslej posvečala domu in soseski ter pri večini ljudi dokazala visoko stopnjo navezanosti (Hidalgo in Hernández, 2001). Nekatere raziskave kažejo, da je dom najpomembnejši kraj identitete, medtem ko druge nakazujejo, da je dom le drugotnega pomena (Cuba in Hummon, 1993). Dve raziskavi sta preučili pomen regije. Hidalgo in Hernández (2001) sta ugotovila, da je soseska manj pomembna od doma 
in regije. Lee Cuba in David M. Hummon's (1993) pa sta v svoji raziskavi dokazala, da je dom pomembnejši od soseske in regije, vendar so bile med njimi majhne razlike.

Hidalgo in Hernández (2001) sta pokazala, da je navezanost na socialno okolje pomembnejša od navezanosti na fizično okolje. Cuba in Hummon (1993) sta v svoji raziskavi opozorila, da je pomembna bližina družine in prijateljev ter drugih socialnih mrež, skupaj s stopnjo vključenosti in sodelovanja v lokalnih organizacijah. Še več, pomembna je identifikacija s prevladujočim življenjskim slogom v soseski. Glavna ugotovitev raziskave je bila, da navezanost na sosesko povzročajo predvsem družbeno udejstvovanje, prijateljske vezi in drugi vzroki, » povezani $s$ prijatelji . Regionalna navezanost je bila povezana $\mathrm{z}$ vzorcem dejavnosti anketirancev v regiji: $\mathrm{z}$ obsegom, $\mathrm{v}$ katerem uporabljajo infrastrukturo v regiji, in do določene mere z močjo socialnih mrež. Ne nazadnje pa je bila navezanost na dom povezana z dojemanjem doma. Druga raziskava (Mesch in Manor, 1998) je pokazala tudi, da lastništvo stanovanja pripomore $k$ močnejši navezanosti na kraj.

\subsection{Povzetek značilnosti, ki so v raziskavah opredeljene kot pomembne}

Na podlagi tega pregleda različnih raziskav o stanovanjskih preferencah, navezanosti na kraj in zadovoljstvu z domom in njegovo okolico lahko oblikujemo ta seznam pomembnih stanovanjskih značilnosti. Značilnosti okolice in lokacije doma, vključene v različne raziskave, so:

- fizično okolje: fizični značaj in videz stavb, ulic in trgov, fizične nadloge, kot so promet, hrup in onesnaženost, standardi vzdrževanja na območju, dostopnost zelenih površin in vode;

- socialno okolje: status in socialno okolje, kriminal in varnost, socialne mreže in navezanost na kraj, življenjski slog;

- lokalne javne in zasebne storitve: trgovine, restavracije, družabne dejavnosti, kultura in zabava, ustanove, športni objekti, igrišča in pogoji za otroke, lokalne socialne mreže in zveze in podobno;

- lokacija in prevoz: oddaljenost delovnega mesta, izobraževalna in urbana središča, možnosti prevoza in oddaljenost sorodnikov in prijateljev.

Pomen vsakega od teh dejavnikov se po posameznih raziskavah nekoliko razlikuje, odvisno od obsega raziskave ter lokacije in značaja obravnavanih gospodinjstev. Glede na vse povedano lahko sklepamo, da so v posameznih raziskavah preferenc poudarjeni vsi štirje zgoraj opisani vidiki. Raziskave o zadovoljstvu stanovalcev poudarjajo fizično in socialno okolje, medtem ko raziskave o navezanosti na kraj pripisujejo največji pomen socialnemu okolju.

\subsection{Kaj povzroča razlike med preferencami?}

Omenjena literatura vsebuje različna mnenja o tem, zakaj se med različnimi gospodinjstvi stanovanjske preference razlikujejo. V nadaljevanju so predstavljeni ti vidiki, ki vplivajo na stanovanjske preference:

- razlike v družinskem statusu in življenjskem obdobju,

- dohodek in drugi viri,

- kultura in življenjski slog.

Razlike v družinskem statusu in spremembe življenjskih obdobij tradicionalno veljajo za najpomembnejše dejavnike, ki vplivajo na stanovanjske potrebe in preference (Skifter Andersen in Bonke, 1980; Clark in Onaka, 1983; Howell in Freese, 1983; Floor in Van Kempen, 1997). Zlasti prihod otrok v družino in njihov odhod iz nje povzročita velike spremembe v stanovanjskih potrebah, zlasti ko si družina ustvari stalen dom. Kadar imajo družine več otrok, se potrebe po prostoru, storitvah in okolju močno spremenijo. Pozneje, ko se otroci odselijo, se potrebe po prostoru zmanjšajo, vendar ni nujno, da se zaradi tega družina preseli v drugo stanovanje, in sicer predvsem zato, ker ljudje drugače izkoristijo prostor, delno pa tudi zato, ker se z leti mobilnost gospodinjstev zelo zmanjša (Rossi, 1955; Skifter Andersen in Bonke, 1980). To se izraža v dejstvu, da v splošnem selitve z leti močno upadejo. Med starejšimi je mobilnost še nižja, čeprav se lahko njihove preference do velikosti, cene, lastništva, vrste stavbe in lokacije močno spremenijo.

Obstaja več razlogov, zaradi katerih stanovanjska pot (ang. housing career) ni vedno enaka pri družinah $\mathrm{z}$ enako družinsko potjo (ang. family career). Prvič, obstajajo razlike med službenimi karierami in povezanim razvojem dohodka, kar pomeni, da se gospodarski viri in z njimi povezane stanovanjske možnosti razlikujejo. Te omejitve se bolj ali manj izražajo v stanovanjskih preferencah, in sicer odvisno od tega, kako realno lahko ljudje ocenijo svoje prihodnje možnosti. Drugič, obstajajo razlike v možnostih, ki jih stanovanjski trg ponuja na različnih zemljepisnih območjih. Zaradi zaposlitve, socialnih vezi in splošne navezanosti na kraj (Hidalgo in Hernándes, 2001; Mulder, 2007) je večina ljudi vezana na določeno zemljepisno območje in bo pogosto tam tudi ostala, čeprav ne najde ustreznih stanovanjskih možnosti. In nazadnje, pojav nekakšne »odvisnosti od poti na stanovanjskem področju « (ang. path dependency in housing; Clapham, 2005) pogosto pripelje do omejitev na stanovanjskem trgu. Stanovanjske želje in odločitve ljudi so večinoma odvisne od njihovega prejšnjega bivališča in stanovanjske poti. Prvič, stanovanje, v katerem je posameznik odraščal, je zelo pomembno, saj se ljudje odločajo za podoben tip stanovanja, kot je bil tisti, $\mathrm{v}$ katerem so odraščali (Ærø, 2002). Dokazano je bilo tudi, da ima prva izbira stanovanja in lokacije po končanem izobraževanju zelo velik vpliv na poznejše stanovanjske odločitve, medtem ko je stanovanje, ki 
ga ljudje izberejo v srednjih letih, najpomembnejše za njihove preference $\mathrm{v}$ tretjem življenjskem obdobju (Howell in Freese, 1983). V nasprotju s tem družinska pot zaradi pogostejših ločitev in menjavanja zaposlitev ni več tako jasna. Zato pričakovanja glede prihodnosti niso več tako statična, kar lahko vpliva na stanovanjske preference, če nameravajo ljudje v svojem stanovanju živeti le začasno (Floor in Van Kempen, 1997).

Razvoj posameznikov v celotnem življenjskem obdobju z vidika zaposlitve in dohodka ima tudi pomemben vpliv na kratkoročne in dolgoročne stanovanjske preference. Ko so ljudje mladi, na lokacijo stanovanja vpliva bližina izobraževalnih ustanov, medtem ko ima pozneje nanjo večji vpliv bližina delovnega mesta. Dohodki in z njimi stanovanjske priložnosti naraščajo od začetka posameznikove službene poti do sredine štiridesetih let, po šestdesetem letu pa se zelo zmanjšajo. Toda tisti, ki živijo v lastnih stanovanjih, si sčasoma hkrati povečajo stanovanjski kapital, kar pomeni, da lahko ohranijo enako raven stanovanjske potrošnje tudi ob manjšem dohodku.

Dokazano je, da na izbiro stanovanja ne vpliva samo trenutni dohodek, temveč tudi pričakovani dohodek do konca posameznikovega življenja (Artle in Varayia, 1978; Wheaton, 1985). Ljudje z višjo izobrazbo imajo v enakih pogojih večja pričakovanja glede prihodnjih dohodkov kot tisti z nižjo izobrazbo, zato tudi raje izbirajo večje in dražje domove v boljših soseskah. Kombinacija tega in »odvisnosti od poti« na stanovanjskem področju je zlasti pomembna za to, v kolikšni meri se posamezniki odločijo ustvariti družino v lastniškem stanovanju. Nekatera gospodinjstva - zlasti tista z visoko izobrazbo ali višjimi dohodki v zgodnjem življenjskem obdobju - zgodaj kupijo dom in v njem ostanejo do konca življenja. Drugi, ki jim ne uspe kupiti doma v obdobju ustvarjanja družine, lahko vse življenje ostanejo v najemniškem stanovanju, čeprav bi si želeli živeti v lastniškem stanovanju (Skifter Andersen in Bonke, 1980).

\subsection{Kultura in življenjski slog}

Ærø (2002) meni, da »kulturne « razlike v veliki meri določajo želje ljudi pri izbiri stanovanj. Deli jih v tri skupine:

- Tisti, ki ne izbirajo (predsodobna modalnost). Tej skupini je samoumevno, kje se počuti doma. Lahko bi rekli, da dom izbere stanovalca in zato ne moremo govoriti o izbiri. Posameznik se počuti doma v določenem kraju, vsi drugi so mu tuji. Kje to je, je odvisno od konvencij in tradicij. Posameznik se ustali tam, kjer so vedno živeli njegovi sorodniki, predniki, prijatelji in sodelavci. Izbira stanovanja ni izražena in ni vprašljiva, poleg tega ni treba pojasnjevati, zakaj nekdo živi v nekem kraju.

- Tisti, ki izbirajo (sodobna modalnost). Pri tej modalnosti je zelo pomembna » pravilna « izbira stanovanja in veliko je razmišljanja o tem, kje živeti. Izbira je racionalno pojasnjena na podlagi ekonomskih ali funkcionalnih razlogov in jo je mogoče pripisati posameznikovemu položaju v družbi, ki je pogosto rezultat vseživljenjske identitete, ki si jo je pridobil z delom.

- Tisti, ki nenehno izbirajo (pozna sodobna modalnost). $\mathrm{V}$ tej skupini izbira stanovanja ni jasna in se nenehno spreminja. Kako naj posameznik izbere »pravi« dom, če današnja prava odločitev jutri mogoče ne bo imela več nobene teže? V svetu brez ustaljenih vrednot je težko in morda tudi nesmiselno izbirati. Dokončna izbira pomeni, da nekaj zavrnemo, kar ni prijetno. Zato posameznik ne izbira in se povsod počuti doma, obenem pa se povsod počuti kot tujec.

Ta teorija kaže na to, da lahko obstajajo velike razlike v pomenu, ki ga ljudje pripisujejo značilnostim doma ter njegove okolice in lokacije. Ljudje iz prve skupine vnaprej izberejo posebne lokacije z določeno socialno, kulturno in fizično vsebino, ker so navezani nanje. Ti ljudje bodo izrazili preference, ki se ujemajo z že obstoječo vsebino, ali pa ne bodo imeli nobenih posebnih preferenc. Podobno tudi tretja skupina nima nobenih močnih preferenc do okolice doma, ima pa jih lahko do lokacije in dostopnosti storitev, prevoza in kulture. Za nekatere je dom samo eden od številnih krajev, v katerih se počutijo doma. Enako domače se počutijo $\mathrm{v}$ krajih, $\mathrm{v}$ katere potujejo ali $\mathrm{v}$ katerih so na počitnicah. Dom je kraj, na katerem se posameznik spočije in spi, medtem ko resnično življenje poteka drugje. Za drugo skupino je dom zelo pomemben temelj družinskega življenja. Zlasti za tiste, ki imajo otroke, sta dom in njegova okolica zelo pomembna, kar se izraža tudi v njihovih preferencah. Ta skupina ima številne in močne preference. Življenjski slog in stopnja navezanosti na kraj lahko torej pojasnita, ali imajo ljudje močne preference do velikega števila vidikov hkrati ali pa imajo samo nekaj res močnih preferenc.

Poleg tega je stanovanjski položaj, ki si ga je družina že ustvarila, lahko bistven za preference, ker se je nanj navadila. Nekatere prednosti lokalne soseske se jim mogoče zdijo samoumevne, ker si ne predstavljajo, da bi živeli kjer koli drugje; to zlasti velja za prvo od treh skupin. Na primer, ljudem, ki živijo na podeželju, se mogoče narava ne zdi nekaj tako pomembnega, da bi postala njihova prioriteta, saj živijo obdani z njo, medtem ko so narava in parki mogoče pomembnejši za tiste, ki tega nimajo in živijo v mestih. Nekateri dajejo prednost izboljšanju pomanjkljivosti in ne prednostim, ki se jim zdijo samoumevne.

\section{Danska raziskava o stanovanjskih preferencah}

Raziskava je zajela 2.500 oseb, starejših od petnajst let. Vzorec je bil naključno izbran iz javnih evidenc danskega statističnega 
urada. Z njimi je bilo opravljenih 1.500 telefonskih pogovorov, kar pomeni, da se jih je na anketo odzvalo $60 \%$. Narejena je bila primerjava med starostno strukturo in deležem spolov anketirancev ter starostno strukturo in deležem spolov celotnega danskega prebivalstva; manjša odstopanja so bila odpravljena s ponderiranjem podatkov. Podatki o starosti, družinskem statusu, dohodku, poklicu in izobrazbi anketirancev so bili dodani iz javnih evidenc. V raziskavi so bile »navedene preference « obravnavane tako, da so bila ljudem postavljena vprašanja o njihovih idealnih stanovanjskih preferencah. Vprašalnik je zajemal teme, kot so preference o lastništvu, velikosti doma, vrsti stavbe, vrsti lokacije ter značilnostih okolice in lokacije. Poleg tega so bila postavljena vprašanja o tem, zakaj se ljudje raje odločijo za najem ali lastništvo.

$\mathrm{V}$ prispevku so analizirane preference o lastnostih in prednostih okolice in lokacije doma. Stanovanjske preference v tej raziskavi so bile ugotovljene tako, da so ljudje odgovarjali na vprašanje, katere prednosti se jim zdijo pomembne pri izbiri doma. Razdelimo jih lahko na pet skupin:

(a) Fizični pogoji

- mir pred hrupom z ulice in podobnim

- bližina zelenih površin

- bližina morja ali jezera

(b) Socialne razmere v soseski

- malo socialnih problemov

- nobenih problemov s kriminalom

- prebivalci se med seboj ne razlikujejo preveč

- ni veliko priseljencev

(c) Pogoji za otroke

- bližina šol in vrtcev

- dobri splošni pogoji za otroke

(d) Storitve in infrastruktura

- javna infrastruktura, kulturni domovi in podobno

- bližina mestnega utripa - kavarne in kulturno življenje

(e) Lokacija in prometna infrastruktura

- dostopnost dobrega javnega prevoza

- bližina delovnega mesta

- bližina prijateljev in sorodnikov

- bližina kraja odraščanja

Anketiranci so odgovarjali, ali so te značilnosti (a) zelo pomembne, (b) pomembne ali (c) niso pomembne. Na tej podlagi je bil izračunan indeks. Indeks 100 pomeni, da so vsi anketiranci menili, da je ta značilnost zelo pomembna, indeks 0 pa, da so vsi menili, da ni pomembna.

\section{Pomembnost različnih preferenc}

Slika 1 ponazarja povprečni indeks pomembnosti preferenc $\mathrm{v}$ vprašalniku. Povprečno je bližina zelenih površin najpomembnejša značilnost, veliko ljudi na Danskem pa daje prednost tudi bližini vode (morja ali jezera). To je mogoče poseben danski pojav, saj ima Danska zelo dolgo obalo. V povezavi z željami po prebivanju blizu narave je za veliko ljudi pomembno, da kraj ni preobremenjen $s$ hrupom. Pri izbiri soseske so zelo pomembne tudi socialne razmere v soseski. To zlasti velja za strah pred kriminalom in vidne socialne probleme. Danska je socialna država, ki ima manj kriminala in socialnih problemov kot večina drugih držav, zato so te razmere pričakovano pomembnejše kot drugje.

Še pred kratkim je imela Danska še kar homogeno prebivalstvo z majhnim številom priseljencev z drugačnimi kulturnimi koreninami in razmeroma malo razrednih razlik. $V$ zadnjih letih, zlasti po letu 1990, so v državo prispeli begunci in priseljenci, ki zdaj pomenijo približno $5 \%$ skupnega prebivalstva. To je že povzročilo nekaj političnih nemirov in razprave, ki priseljence predstavljajo zelo negativno. Pojavila pa se je tudi že določena etnična segregacija in koncentracija priseljencev v nekaterih neprofitnih stanovanjih. Toda to v splošnem pri Dancih ni povzročilo močnih preferenc do tega, da bi se izogibali soseskam z veliko priseljenci. Kot je razvidno s slike 1, je življenje $\mathrm{v}$ soseski z malo priseljenci povprečno ocenjeno kot »sploh ni pomembno « do »nekoliko pomembno «. Čeprav ima samo manjši del gospodinjstev otroke, so pogoji za otroke in bližina šol in vrtcev za Dance zelo pomembni. To vprašanje je podrobneje predstavljeno v nadaljevanju. Samo nekaj gospodinjstev pa daje prednost javni infrastrukturi v soseski, kot so na primer kulturni domovi.

Ena od preferenc se nanaša na bližino življenja in storitev v velikih mestih. V splošnem je samo manjši del anketirancev tej lastnosti pripisal poseben pomen. Kot je prikazano v nadaljevanju, je to povezano $\mathrm{z}$ določenimi skupinami, zlasti z mladimi samskimi osebami in $s$ pari brez otrok. Danska ima dober sistem javnega prevoza in njegova dostopnost je za mnoge anketirance pomembna, še celo pomembnejša od bližine delovnega mesta. Pomembne so tudi socialne mreže, zlasti bližina sorodnikov in prijateljev. Samo za nekatere pa je pomembno živeti blizu kraja, v katerem so odraščali.

\section{Korelacija med različnimi preferencami do okolice in lokacije}

Da bi bolje razumeli, kaj se skriva za preferencami do lokacije in okolice, smo analizirali interakcije med preferencami. Poleg tega je bila za interpretacijo skritih vzrokov uporabljena faktorska analiza. Prejšnji opis stareǰ̌ih raziskav se nanaša na Ærøvo raziskavo (2002), ki kaže, da imajo nekateri ljudje zaradi razlogov, povezanih z življenjskih slogom, močne preference do velikega števila vidikov hkrati, drugi pa jih imajo samo malo. Še več, stanovanjske razmere, ki si jih je družina že 


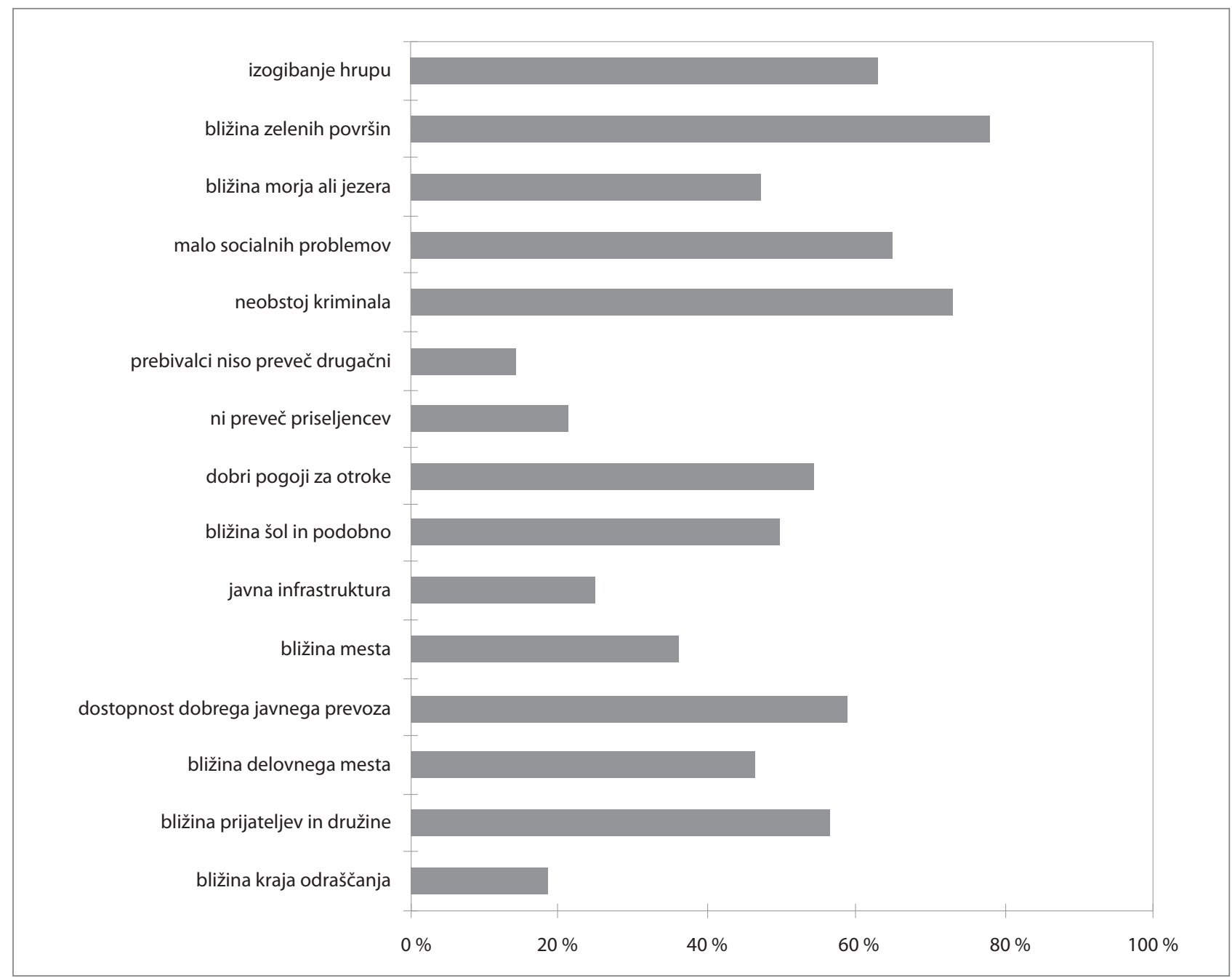

Opomba: $100=$ zelo pomembno, $0=$ ni pomembno

Slika 1: Povprečni indeks pomembnosti preferenc do okolice in lokacije doma

zagotovila, so lahko bistvene za njihove preference, saj so se tem razmeram prilagodili. Nekatere značilnosti okolja so jim lahko samoumevne (mogoče zlasti prvi od treh Ærøvih skupin), saj si ne morejo predstavljati, da bi živeli drugje.

Verjetno obstaja med nekaterimi preferencami neposredna korelacija. To zlasti velja za fizične in socialne razmere ter pogoje za otroke, čeprav obstaja pozitivna korelacija med skoraj vsemi spremenljivkami. To pomeni, da so nekateri pritrdilno odgovorili na veliko vprašanj, medtem ko so nekateri dali prednost samo nekaterim. To potrjuje Ærøvo hipotezo, da imajo nekatere družine veliko prioritet in pričakovanj glede okolice in lokacije doma, medtem ko jih imajo drugi le malo. Ena od skupin (tretja skupina: tisti, ki nenehno izbirajo) bo verjetno imela zelo močno željo po tem, da ostane blizu mestnega utripa ali dobrih prometnih povezav. Prva skupina (tisti, ki ne izbirajo, ker je odločitev o kraju bivanja samoumevna glede na to, da tam živijo njihovi sorodniki in prijatelji) pa želi živeti blizu kraja, v katerem je odraščala. Kot se je izkazalo, se ti preferenci redko ujemata z drugimi preferencami, preferenca do mestnega utripa in dostopnosti javnega prevoza pa je negativno povezana z željo po prebivanju blizu kraja, $\mathrm{v}$ katerem je posameznik odraščal. Zato imata ti preferenci zelo različni skupini.

Glede preferenc do socialnih razmer obstaja zelo močna povezava med željo po izogibanju socialnim problemom in željo po izogibanju kriminalu (preglednica 2). Odnos ni tako močan kot pri želji po izogibanju priseljencem in želji po prebivalcih, ki ne bi bili preveč drugačni. Kljub temu obstaja razmeroma močna povezava med željo po izogibanju priseljencem in željo po prebivalcih, ki ne bi bili preveč drugačni.

V splošnem obstaja šibka korelacija med preferencami do socialnega okolja in drugimi preferencami. Na primer povezava z zahtevami po dobrih pogojih za otroke je presenetljivo šibka (največ 0,10). Edini drugi dejavnik, ki se povezuje s socialnimi preferencami, je želja po izogibanju hrupu, kot je razvidno iz preglednice 2. To pomeni, da se želijo nekateri ljudje sočasno 
Preglednica 2: Statistična korelacija med preferencami do socialnega okolja doma in do izogibanja hrupu

\begin{tabular}{lllll}
\hline & $\begin{array}{l}\text { Malo } \\
\text { socialnih } \\
\text { problemov }\end{array}$ & $\begin{array}{l}\text { Brez } \\
\text { kriminala }\end{array}$ & $\begin{array}{l}\text { Ne preveč } \\
\text { drugačni } \\
\text { prebivalci }\end{array}$ & $\begin{array}{l}\text { Malo } \\
\text { priseljencev }\end{array}$ \\
\hline $\begin{array}{l}\text { neobstoj } \\
\text { kriminala }\end{array}$ & 0,71 & & & \\
\hline $\begin{array}{l}\text { ne preveč } \\
\text { drugačni } \\
\text { prebivalci }\end{array}$ & 0,19 & 0,15 & & \\
\hline $\begin{array}{l}\text { malo } \\
\text { priseljencev }\end{array}$ & 0,27 & 0,25 & 0,38 & \\
\hline $\begin{array}{l}\text { izogibanje hrupu } \\
0,37\end{array}$ & 0,34 & 0,11 & 0,11 \\
\hline
\end{tabular}

izogniti socialnim problemom in hrupu. Po pričakovanjih obstaja močna korelacija med željo po bližini zelenih površin in želji po bližini vode $(0,39)$. Obstaja tudi določena povezava med željo po zelenih površinah in željo po izogibanju hrupu $(0,25)$, kar pomeni, da ti ljudje pripisujejo velik pomen mirnemu, podeželskemu okolju. Preference do dobrih pogojev za otroke so tesno povezane z željo po dobrih šolah in vrtcih $(0,67)$, do določene mere pa tudi z željo po javni infrastrukturi v soseski $(0,19)$. Korelacija med preferencami do življenja $»$ blizu mestnega utripa « in skoraj vsemi drugimi preferencami je nizka, $v$ nekaterih primerih pa celo negativna. Med takimi primeri so želja po bližini zelenih površin, izogibanju hrupu in dobrih pogojih za otroke. Vse druge preference imajo zelo majhno vlogo pri tistih, ki hočejo živeti v mestnem središču. Večja je korelacija z lokacijskimi spremenljivkami, kot so dobre prometne povezave $(0,21)$ in bližina delovnega mesta/šole $(0,17)$. Nazadnje pa obstaja tudi razmeroma dobra korelacija med željo po prebivanju blizu prijateljev in družine ter željo po prebivanju blizu kraja odraščanja $(0,26)$. Oba dejavnika se do določene mere povezujeta z željo po prebivanju blizu delovnega mesta in šole $(0,19$ in 0,14$)$, z drugimi spremenljivkami pa sta različno povezana. Med žljo po prebivanju blizu prijateljev in družine ter željo po izogibanju socialnim problemom in kriminalu $(0,11$ in 0,14$)$ obstaja šibka korelacija, medtem ko se želja po prebivanju blizu kraja odraščanja do določene mere povezuje z željo po izogibanju priseljencem in življenju v kraju, $\mathrm{v}$ katerem drugi prebivalci niso preveč drugačni $(0,11$ in 0,13$)$.

\section{Faktorska analiza za oblikovanje novih spremenljivk, ki bi pojasnile preference do okolice in lokacije doma}

Faktorska analiza se uporablja za določanje skritih spremenljivk ali dejavnikov, ki pojasnijo vzorec korelacij v nizu obravnavanih spremenljivk. Pogosto se uporablja pri krčenju po- datkov za določanje majhnega števila dejavnikov, ki pojasnijo večino variance, ugotovljene $\mathrm{v}$ veliko večjem številu očitnih spremenljivk. Faktorsko analizo lahko uporabimo za oblikovanje hipotez o vzročnih mehanizmih ali izbiro spremenljivk za nadaljnjo analizo.

Kot je pokazala analiza korelacij med odgovori, pridobljenimi v anketi, obstaja med nekaterimi preferencami do okolice in lokacije medsebojna odvisnost, med drugimi pa ne. Da bi ugotovili, do katere mere obstaja vzorec $\mathrm{v}$ teh odnosih, smo za petnajst prej naštetih spremenljivk uporabili faktorsko analizo. $\mathrm{V}$ tem primeru je bil namen analize oblikovati nove prečne spremenljivke ali dejavnike, ki povzemajo in pojasnjujejo vzorce, ki se skrivajo za prvotnimi odgovori.

Analiza je opredelila šest dejavnikov, ki pojasnijo dve tretjini variance med navedenimi preferencami. Preglednica 3 prikazuje korelacijo med vsako od šestih faktorskih spremenljivk in vsako od vhodnih spremenljivk, ki predstavljajo odgovore v anketi. Preglednico lahko uporabimo za interpretacijo pomena šestih faktorskih spremenljivk:

- Dejavnik 1: izogibanje socialnim tegobam Ta dejavnik je zelo močno povezan s preferenco do socialnih vprašanj, povezanih s stanovanji (socialni problemi in kriminal), in tudi do hrupa.

- Dejavnik 2: dobri pogoji za ustvarjanje družine Najpomembnejše spremenljivke so dobri pogoji za otroke, dobre šole in podobno ter javna infrastruktura. Pomembna je tudi bližina delovnega mesta.

- Dejavnik 3: socialna homogenost Prebivalci soseske ne smejo biti preveč drugačni in po možnosti naj bi bili Danci. To se do neke mere ujema z željo po prebivanju blizu kraja odraščanja.

- Dejavnik 4: blizu narave in mirne okolice Pomembno je stanovati blizu zelenih površin in vode, (v določeni meri) pa tudi izogibanje hrupu.

- Dejavnik 5: blizu socialnih mrež Najpomembnejše je ostati blizu kraja odraščanja in/ali prijateljev in družine. Pomembna je tudi bližina delovnega mesta.

- Dejavnik 6: blizu mestnega utripa in javnega prevoza Pomembno je ostati blizu mestnega utripa in dobrih javnih prometnih povezav. Tu sta pomembni tudi javna infrastruktura v soseski in bližina službe.

Analiza je torej pokazala, da lahko preference do okolice in lokacije doma razdelimo na šest vidikov. Prvi vidik, »izogibanje socialnim tegobam «, je najpomembnejši (kot je ponazorjeno na sliki 1), saj sta izogibanje socialnim problemom in kriminalu zelo pomembni preferenci. Dejavnik je do neke mere povezan tudi z željo po prebivanju v soseski, $v$ kateri ni preveč priseljencev. Ljudem, pri katerih prevladuje ta dejavnik, 
Preglednica 3: Izsledki faktorske analize navedenih preferenc (korelacija med dejavniki in vhodnimi spremenljivkami)

\begin{tabular}{|c|c|c|c|c|c|c|}
\hline \multirow{2}{*}{ Preference } & \multicolumn{6}{|c|}{ Novi dejavniki } \\
\hline & 1 & 2 & 3 & 4 & 5 & 6 \\
\hline izogibanje hrupu & 0,61 & 0,13 & $-0,02$ & 0,24 & $-0,07$ & $-0,07$ \\
\hline malo socialnih problemov & 0,87 & 0,02 & 0,18 & 0,06 & 0,08 & $-0,01$ \\
\hline neobstoj kriminala & 0,86 & 0,02 & 0,14 & 0,03 & 0,07 & 0,09 \\
\hline bližina šol in vrtcev & 0,10 & 0,87 & 0,01 & $-0,02$ & 0,11 & 0,01 \\
\hline dobri splošni pogoji za otroke & 0,07 & 0,88 & 0,02 & 0,06 & 0,05 & 0,00 \\
\hline javna infrastruktura, kulturni domovi in podobno & $-0,06$ & 0,34 & 0,14 & 0,18 & $-0,08$ & 0,43 \\
\hline ne preveč drugačni prebivalci & 0,05 & 0,10 & 0,83 & 0,05 & 0,02 & 0,03 \\
\hline malo priseljencev & 0,22 & $-0,05$ & 0,75 & 0,04 & 0,07 & 0,07 \\
\hline bližina zelenih površin & 0,21 & 0,15 & 0,04 & 0,78 & 0,01 & 0,03 \\
\hline bližina morja ali jezera & 0,08 & $-0,07$ & 0,05 & 0,81 & 0,08 & 0,06 \\
\hline dostopnost dobrega javnega prevoza & 0,07 & 0,04 & $-0,08$ & 0,05 & 0,12 & 0,70 \\
\hline bližina mestnega utripa: kavarn in kulturnega življenja & $-0,04$ & $-0,11$ & 0,13 & $-0,04$ & 0,04 & 0,72 \\
\hline bližina delovnega mesta & 0,08 & 0,22 & $-0,15$ & $-0,17$ & 0,52 & 0,27 \\
\hline bližina prijateljev in sorodnikov & 0,08 & $-0,04$ & 0,01 & 0,11 & 0,73 & 0,18 \\
\hline bližina kraja odraščanja & $-0,09$ & 0,08 & 0,23 & 0,09 & 0,73 & $-0,22$ \\
\hline pojasnjeni delež variance vhodnih spremenljivk (\%) & 18,3 & 11,5 & 9,7 & 8,1 & 7,7 & 7,5 \\
\hline lastne vrednosti & 2,74 & 1,72 & 1,45 & 1,22 & 1,15 & 1,12 \\
\hline
\end{tabular}

Opomba: analiza z rotacijo Varimax

je po navadi zelo pomemben status njihove soseske (socialni problemi, kriminal in priseljenci nedvomno vodijo $\mathrm{k}$ slabi podobi in nizkemu statusu soseske) ali pa se nekoliko bojijo svoje okolice in imajo veliko potrebo po varnosti (Skifter Andersen, 2008). To potrjuje tudi dejstvo, da je izogibanje hrupu v tej skupini zelo pomembno.

Kot kaže analiza korelacij med spremenljivkami preferenc, je zahteva po socialni homogenosti soseske poseben vidik, ločen od dejavnika socialnih tegob in podobnega, čeprav obstajajo šibke korelacije s socialnimi težavami in kriminalom. To je zanimivo: če strah pred življenjem med tujci ni povezan $s$ konkretnimi socialnimi problemi in kriminalom, kaj je torej razlog? Mogoče je povezan z dejstvom, da obstaja korelacija s preferenco do življenja blizu kraja odraščanja? To je opisano $\mathrm{v}$ nadaljevanju, in sicer $\mathrm{v}$ delu, ki obravnava povezavo med tem dejavnikom in preferencami do življenja v mestu ali na podeželju.

Četrti dejavnik, »blizu narave in mirne okolice«, prav tako obsega preference, ki so mnogim pomembne (bližina zelenih površin in vode). To je do neke mere povezano z željo po tihi in mirni okolici. Ta dejavnik je negativno povezan z željo po prebivanju blizu mestnega utripa, vendar manj, kot bi pričakovali. Večina teh ljudi torej ne daje prednosti mestnemu življenju, čeprav mu jo nekateri dajejo. Za nekatere ljudi, ki raje živijo v mestu, je lahko zelo pomembna bližina parkov. Lahko tudi vidimo, da je ta dejavnik bolj negativno povezan z željami po prebivanju blizu delovnega mesta. To lahko pomeni, da ljudje, pri katerih prevladuje ta dejavnik, niso zaposleni (kar je razvidno v nadaljevanju) ali pa so se pripravljeni na delo vsakodnevno voziti v zameno za življenje blizu naravnega okolja. Nazadnje pa je ta dejavnik v manjši meri povezan z željo po socialnih mrežah in javni infrastrukturi. Zaradi tega lahko nekateri ljudje povezujejo preferenco do življenja na podeželju $\mathrm{z}$ željo pridružiti se tesno povezani skupnosti v takih krajih (Skifter Andersen, v tisku). Obstaja tudi šibka korelacija med preferencami do dobrih pogojev za otroke in bližine zelenih površin, izogibanja hrupu in življenja v krajih, $\mathrm{v}$ katerih prebivalci niso preveč drugačni. Razlog za vse to bi lahko bili tudi otroci. Po drugi strani pa obstaja negativna korelacija $s$ preferencami do življenja v mestu.

Za razlago zadnjih dveh dejavnikov lahko uporabimo Ærøvo delitev (2002) na predsodobno, sodobno in pozno sodobno modalnost. Dejavnik »blizu socialnim mrežam « lahko povežemo s predsodobno modalnostjo, medtem ko lahko dejavnik »blizu mestnega utripa « povežemo s pozno sodobno modalnostjo. Dejavnik »blizu socialnim mrežam « je močno povezan s preferencami do življenja blizu kraja odraščanja, sorodnikov in prijateljev. Ni pa povezan z nobeno drugo preferenco, razen $s$ preferencami do bližine delovnega mesta. Lahko bi rekli, da se ljudje, pri katerih prevladuje ta dejavnik, ne odločajo za nič drugega kot pa za življenje v natančno določenem kraju - večinoma v tistem, v katerem so odraščali. Dejavnik »blizu mestnega utripa « ima močno korelacijo s preferencami do mestnega življenja, dostopnosti javnega prevoza in javne infrastrukture. Poleg tega je pomembna tudi bližina delovne- 
ga mesta. Ima pa negativno korelacijo z željo po prebivanju v kraju odraščanja, čeprav so družina in prijatelji (mogoče zlasti slednji) do neke mere pomembni. Vse druge preference niso pomembne pri tem dejavniku. Z lahkoto bi ga lahko povezali s skupino ljudi pozne sodobne modalnosti, pri katerih prevladuje želja po dostopnosti mestnega življenja in prevoza, medtem ko številne druge preference niso pomembne.

\section{Povezava med želeno stopnjo urbanizacije in dejavniki preferenc}

Po pričakovanju obstaja močna povezava med navedenimi preferencami do okolice in tem, ali ljudje raje živijo v mestu ali na podeželju. $V$ preglednici 4 so prikazani povprečni rezultati dejavnikov (pomnoženi s sto) za anketirance, ki so razdeljeni glede na navedene preference do življenja v velikih in manjših mestih, vaseh ali na podeželju. Rezultati so v razponu od -100 do 100 (po navadi od -1 do 1 ).

Zadnji stolpec preglednice 4 kaže delež anketirancev glede na želeno lokacijo. Malo manj kot polovica si želi živeti v velikih mestih, v predmestjih ali blizu mestnega središča. Eden od štirih ima raje majhno ali srednje veliko mesto, $13 \%$ si želi živeti na vasi in $15 \%$ na podeželju. V primerjavi s tem, kje živijo, si nekoliko več ljudi želi živeti na podeželju kot v svojem sedanjem domu. Manj ljudi želi živeti v gosto poseljenih območjih blizu mestnega jedra, kot pa jih tam dejansko živi. Tisti, ki raje živijo v mestnem središču, so pričakovano tudi pod močnim vplivom dejavnika »blizu mestnega utripa «, ta vpliv pa strmo upade z manj urbanizacije. Toda do neke mere je pomemben tudi v predmestjih. Preference do bližine narave imajo pričakovano obratno povezavo $s$ preferencami do stopnje urbanizacije. To je zelo močno izraženo pri ljudeh, ki raje živijo v vaseh in na podeželju, in zelo šibko pri tistih, ki raje živijo v mestu.

Ta povezava do neke mere obstaja tudi pri dejavniku »socialne mreže «. Ta je močnejši v predmestjih, mestih in vaseh ter šibek pri ljudeh, ki hočejo živeti v mestnih jedrih. Nekoli- ko presenetljivo je tudi šibkejši v povezavi s preferencami do življenja na podeželju. Ena razlaga tega bi lahko bila, da je življenje na podeželju povezano $\mathrm{z}$ določeno socialno izoliranostjo, ker so sosedje bolj oddaljeni. Pri drugih treh dejavnikih je mogoče zaslediti manj jasno variacijo $\mathrm{v}$ povezavi z želeno stopnjo urbanizacije. Zaskrbljenost zaradi socialnih problemov je največja v predmestjih in na urbanih območjih blizu mestnih jeder (mogoče zato, ker je tam $\mathrm{v}$ zadnjih tridesetih letih veliko problemov) ter do neke mere $\mathrm{v}$ podeželskih mestih. Najmanj pomembna je $\mathrm{v}$ mestnih jedrih, sledijo jim vasi. Prvi razlog bi lahko bil ta, da so ljudje, ki raje živijo v mestnih jedrih, bolj svetovljanski in strpnejši do socialnih problemov in se ne bojijo morebitnega kriminala. Drugi razlog bi lahko bila tudi starost te skupine, kot je predstavljeno $\mathrm{v}$ nadaljevanju. Za podeželje pa bi lahko veljala razlaga, da socialni problemi tam niso tako vidni.

Dajanje prednosti dobrim pogojem za otroke je močno zastopano na gosto poseljenih območjih blizu mestnih jeder. Pomembnejše je zato, ker je tam veliko manj družin z otroki, medtem ko jih je v predmestjih veliko. Razlog za to je lahko dejstvo, da so pogoji za otroke najpomembnejši na območjih, kjer so najslabši. Preference do dobrih pogojev za otroke so močne tudi v vaseh. Najmanj pomembne so na podeželskih območjih, kjer pogoji veljajo za odlične, razen velike oddaljenosti šol in drugih ustanov.

Preference do socialne homogenosti so najnižje na urbanih območjih blizu mestnih jeder. Razlog za to bi lahko bil ta, da so ta območja pogosto zelo mešana. Ljudje, ki živijo v bližini ali poznajo ta območja, so navajeni na heterogeno prebivalstvo. To pa ne velja vedno v predmestjih, ki so razdeljena v različne soseske s prebivalci iz različnih družbenih razredov in etničnih skupin. Nekoliko presenetljiv je podatek, da ljudje, ki imajo raje mestna središča, gojijo nekoliko večjo preferenco do socialne homogenosti. Mogoče je to posledica vse večje gentrifikacije mestnih jeder zaradi priseljevanja premožnejših skupin. Na podeželju socialna homogenost ni pomembna, saj ljudje največkrat živijo daleč stran od sosedov.

Preglednica 4: Povprečni rezultati dejavnikov (pomnoženi s sto) za ljudi z različnimi preferencami do lokacije doma

\begin{tabular}{llllllll}
\hline Želena lokacija & $\begin{array}{l}\text { lzogibanje } \\
\text { socialnim } \\
\text { tegobam }\end{array}$ & $\begin{array}{l}\text { Pogoji } \\
\text { za otroke }\end{array}$ & $\begin{array}{l}\text { Socialna } \\
\text { homogenost }\end{array}$ & $\begin{array}{l}\text { Blizu } \\
\text { narave }\end{array}$ & $\begin{array}{l}\text { Socialne } \\
\text { mreže }\end{array}$ & $\begin{array}{l}\text { Blizu } \\
\text { mestnega } \\
\text { utripa }\end{array}$ & $\begin{array}{l}\text { Delež glede na } \\
\text { želeno lokacijo } \\
(\%)\end{array}$ \\
\hline središč velikega mesta & $-29,3$ & $-19,9$ & 3,4 & $-28,1$ & $-6,4$ & 60,4 & 17,0 \\
\hline $\begin{array}{l}\text { gosto poseljena območja } \\
\text { blizu mestnih jeder }\end{array}$ & 10,6 & 15,4 & $-25,8$ & $-22,9$ & $-13,1$ & 42,5 & 5,0 \\
\hline predmestja & 11,4 & 5,4 & 5,7 & $-2,6$ & 5,3 & 12,9 & 26,0 \\
\hline majhna ali srednje velika mesta & 6,7 & 2,3 & 2,2 & $-2,6$ & 5,2 & $-11,9$ & 24,0 \\
\hline vas & $-3,4$ & 14,2 & $-0,8$ & 24,2 & 4,7 & $-42,5$ & 13,0 \\
\hline podeželje & 1,2 & $-9,7$ & $-8,7$ & 25,1 & $-11,2$ & $-45,7$ & 15,0 \\
\hline vse & & & & & & & 100,0 \\
\hline
\end{tabular}




\section{Povezava med življenjskimi obdobji in preferencami}

Najprej smo opravili statistične regresijske analize, da bi ugotovili povezavo med spremenljivkami ozadja gospodinjstev in njihovimi stanovanjskimi preferencami. Analize so dale slabe rezultate. Težko je bilo opredeliti modele, ki bi pojasnili variacije med preferencami. Spremenljivke, kot sta dohodek in izobrazba, niso bile pomembne. Najpomembnejše spremenljivke so bile tiste, ki jih lahko povežemo z življenjskimi ciklusi družin. Ena verjetna razlaga bi lahko bila ta, da povezavo med razpoložljivimi spremenljivkami ozadja in preferencami moti dejstvo, da imajo nekateri ljudje veliko število močnih preferenc, medtem ko jih imajo drugi malo; to odstopanje obstaja pri spremenljivkah, kot sta dohodek in izobrazba.

Kot je bilo že opisano v poglavju o starejših raziskavah stanovanjskih preferenc, se preference pričakovano spremenijo glede na posameznikovo življenjsko obdobje. To vprašanje je predstavljeno v tem poglavju s pomočjo spremenljivk dejavnikov, ugotovljenih $s$ faktorsko analizo. Obenem lahko preučimo, kako se ti dejavniki spreminjajo po različnih skupinah glede na življenjska obdobja, kar lahko prispeva $\mathrm{k}$ boljšemu razumevanju pomena teh dejavnikov. Anketiranci so bili razdeljeni na devet skupin glede na življenjsko obdobje, kot je prikazano $\mathrm{v}$ preglednici 5. Ta delitev temelji na podatkih o starosti in družinskih razmerah, pridobljenih iz javnih evidenc. V 7 \% primerov so anketiranci živeli v mešanih gospodinjstvih, $\mathrm{v}$ katerih skupaj živi več ljudi, ki med seboj niso v sorodu. To so bili večinoma mladi. $9 \%$ anketirancev so sestavljali mladi, ki še živijo pri starših.

Glede pomena ugotovljenih dejavnikov je iz preglednice 6 razvidno, da se dejavnik »socialna homogenost « večinoma pojavlja pri starejših in zlasti pri samskih. Analiza specifičnih

Preglednica 5: Anketiranci, razdeljeni v skupine glede na življenjska obdobja.

\begin{tabular}{lll}
\hline $\begin{array}{l}\text { Skupina glede } \\
\text { na življenjsko obdobje }\end{array}$ & $\begin{array}{l}\text { Število } \\
\text { anketirancev }\end{array}$ & $\begin{array}{l}\text { Delež } \\
(\%)\end{array}$ \\
\hline stanuje pri starših & 137 & 9,0 \\
\hline mladi samski <30 & 28 & 1,8 \\
\hline mladi pari <30 & 50 & 3,3 \\
\hline pari z otroki & 454 & 29,7 \\
\hline samohranilci & 46 & 3,0 \\
\hline samski 30-59 & 79 & 5,2 \\
\hline pari 30-59 & 210 & 13,7 \\
\hline starejši pari 60+ & 309 & 20,2 \\
\hline starejši samski 60+ & 108 & 7,1 \\
\hline mešana gospodinjstva & 107 & 7,0 \\
\hline skupaj & 1.528 & 100 \\
\hline
\end{tabular}

odgovorov na vprašanja v anketi je pokazala, da zlasti starejši pogosto navedejo preferenco do izogibanja soseskam $s$ številnimi priseljenci. To bi lahko potrdilo domnevo, da pri izbiri stanovanja ta dejavnik bolj vpliva na ljudi z manj svetovljanskim pogledom na svet, kot so številni starejši. Skupini, na kateri ta dejavnik najmanj vpliva, sta samski srednjih let in samohranilci. Ni pa jasno, zakaj imajo mladi samski (nizek) pozitiven rezultat pri tem dejavniku. Še težje je pojasniti, zakaj ima ista skupina največji negativni rezultat pri dejavniku »izogibanje socialnim tegobam $\ll$.

Nekoliko presenetljivo je tudi to, da je dejavnik »socialne mreže « pomembnejši za mlade kot za starejše. Tu sta mogoči dve razlagi. Prvič, mladi, ki so zaradi šolanja zapustili svoj rojstni kraj in odšli v oddaljeno mesto, pripisujejo zelo velik pomen vrnitvi v kraj, v katerem so odraščali. Za starejše, ki tam živijo že vse življenje, je to samoumevno. Drugič, mladi ljudje s šibkimi mrežami prijateljev in brez svoje družine pripisujejo velik pomen življenju blizu svojih prijateljev, medtem ko je socialna mreža za starejše nekaj samoumevnega ali pa nekaj, kar sploh ne obstaja. Kljub temu je presenetljivo, da ima dejavnik »socialne mreže « tako majhen pomen med starejšimi. $30 \%$ anketirancev, starejših od šestdeset let, je navedlo, da jim bližina sorodnikov in prijateljev ni pomembna.

Preglednica 6 ponazarja, kako se preference do okolice in lokacije doma spreminjajo v življenju posameznika. Toda treba se je zavedati, da ti podatki razkrivajo preference prečnega prereza prebivalstva in da lahko obstajajo razlike med posameznimi generacijami. Iz preglednice 6 lahko naredimo te sklepe o razvoju preferenc v življenjskem ciklusu. Ko si mladi, ki živijo doma, poskušajo najti svoje stanovanje, je zelo pomembno, da stanujejo blizu mestnega utripa. Veliko pomena pripisujejo tudi bližini socialnih mrež. Zanje je pomembno, da živijo blizu prijateljev in morda tudi blizu sorodnikov. Nekateri se še vedno počutijo kot otroci, zato so zanje pomembni dobri pogoji za otroke oziroma športni objekti, mladinski klubi in podobno. Bližina narave ni pomembna. Ko enkrat zapustijo dom in zaživijo kot mladi samski, postanejo preference do mestnega življenja še izrazitejše. Socialne tegobe, pogoji za otroke in narava niso pomembni. Socialne mreže so pomembne, toda ne toliko kot takrat, ko so še živeli doma. Samski srednjih let (30-59 let) imajo še vedno preference do mestnega življenja, toda ne tako izrazite kot mladi. Od mladih samskih se razlikujejo po tem, da imajo zelo nizke preference do socialne homogenosti v svoji soseski in tudi do socialnih mrež. Mogoče lahko to delno pojasnimo z razliko med generacijami, saj je javna zaskrbljenost nad soseskami z veliko priseljenci in socialnimi težavami postala opaznejša v zadnjih dvajsetih letih.

Ko se mladi pari preselijo pod isto streho in ustvarijo temelje za družino, se preference začnejo spreminjati. Bližina mestnega 
Preglednica 6: Povprečni rezultati (pomnoženi s 100) za dejavnike, ki pojasnjujejo preference do okolja in lokacije doma v različnih življenjskih obdobjih.

\begin{tabular}{llllllc}
\hline $\begin{array}{l}\text { Skupina glede } \\
\text { na življenjsko } \\
\text { obdobje }\end{array}$ & $\begin{array}{l}\text { lzogibanje } \\
\text { socialnim } \\
\text { tegobam }\end{array}$ & $\begin{array}{l}\text { Dobri pogoji } \\
\text { za otroke }\end{array}$ & $\begin{array}{l}\text { Socialna } \\
\text { homogenost }\end{array}$ & $\begin{array}{l}\text { Bližina } \\
\text { narave }\end{array}$ & $\begin{array}{l}\text { Socialne } \\
\text { mreže }\end{array}$ & $\begin{array}{l}\text { Bližina } \\
\text { mestnega } \\
\text { utripa }\end{array}$ \\
\hline stanuje pri starših & -8 & 22 & -6 & -57 & 36 & 44 \\
\hline mladi samski $<30$ & -54 & -52 & 13 & -98 & 12 & 46 \\
\hline mladi pari <30 & -4 & -3 & -9 & -27 & 20 & 14 \\
\hline pari z otroki & 12 & 59 & -8 & -2 & 6 & -19 \\
\hline samohranilci & 7 & 50 & -15 & -16 & -17 & -1 \\
\hline samski $30-59$ & -4 & -37 & -34 & 1 & -13 & 19 \\
\hline pari 30-59 & 7 & -25 & 2 & 8 & -12 & -12 \\
\hline starejši pari $60+$ & -10 & -45 & 13 & 34 & -15 & -6 \\
\hline starejši samski $60+$ & 5 & -86 & 42 & 28 & -22 & 18 \\
\hline mešana gospodinjstva & -15 & -24 & -2 & -1 & 12 & 13 \\
\hline
\end{tabular}

utripa je še vedno pomembna, vendar ne toliko kot za mlade samske. Pomembnejša postane bližina socialnih mrež, medtem ko socialne tegobe in pogoji za otroke niso več tako nepomembni. Pari srednjih let (30-59 let) brez otrok imajo nekoliko drugačne preference. $V$ tej skupini mogoče prevladujejo ljudje, ki so se odpovedali misli na otroke ali ki so jih imeli že prej. Večina noče živeti blizu mestnega utripa, vseeno jim je za dobre pogoje za otroke in socialne mreže, toda nekateri imajo preference do narave, socialne homogenosti in izogibanja socialnim problemom. Toda največjo spremembo v preferencah lahko opazimo, ko ljudje dobijo otroke. Pogoji za otroke postanejo najpomembnejša preferenca, bližina mestnega utripa pa najmanj pomembna. Značilna je tudi zelo visoka preferenca do izogibanja socialnim tegobam, kar lahko pojasnimo tudi s skrbjo za otroke. Socialne mreže so še vedno malo pomembne. Samohranilci se ne razlikujejo zelo od parov z otroki.

Preference se zelo spremenijo med starejšimi pari in samskimi nad šestdeset let. Prevladujoča in osrednja preferenca postaneta bližina narave in socialna homogenost. Obstajajo razlike med samskimi in pari, kar lahko do neke mere pojasnimo z dejstvom, da so samski povprečno starejši. Nekateri samski ljudje želijo živeti blizu mestnega utripa, medtem ko pari tega ne želijo. Samske tudi veliko bolj skrbi socialna homogenost in $\mathrm{v}$ manjši meri tudi socialni problemi. Imajo tudi preference do narave, vendar jim je to manj pomembno kot parom. Nekoliko presenetljivo pa je, da imajo samski manjšo preferenco do socialnih mrež, saj bi pričakovali, da je to pomembnejše ljudem, ki živijo sami.

\section{Sklep}

V tem prispevku so podani odgovori na ta vprašanja:

- Katere lastnosti okolice in lokacije doma so najpomembnejše?
- Kako lahko pojasnimo odstopanja v preferencah do teh lastnosti?

- Kako se preference spreminjajo v različnih življenjskih obdobjih?

- Katere so razlike med ljudmi z različnimi preferencami do življenja v mestu ali na podeželju?

Stanovanjske preference v tej raziskavi so bile ugotovljene $s$ spraševanjem naključnega vzorca ljudi na Danskem, starejših od petnajst let, o tem, katere lastnosti okolice in lokacije doma so najpomembnejše pri njihovi izbiri doma. Obstajata dva razloga za to, zakaj je stanovanjske preference težko določiti in zakaj je treba rezultate takih raziskav previdno obravnavati. Prvič, navedene preference včasih ne upoštevajo, $v$ kolikšni meri so uresničljive. Ljudje z enakimi osnovnimi preferencami lahko podajo različne odgovore, ker različno presojajo njihovo uresničljivost. Drugič, na način, na katerega ljudje opredelijo svoje želje v povezavi s svojo prihodnjo izbiro doma, lahko vplivajo njihove sedanje stanovanjske razmere in zlasti sedanje pomanjkljivosti, ki si jih zelo želijo odpraviti. Na primer ljudje, ki živijo v mestih, kjer ni veliko zelenih površin, imajo lahko večjo preferenco do zelenih površin kot ljudje, ki živijo na podeželju, kjer je narave v izobilju. Preference so nedvomno povezane s sedanjimi stanovanjskimi razmerami in z okolišcinami, v katerih ljudje vidijo svoje prihodnje bivališče. Nekatere preference do lokacije in okolice doma veljajo za samoumevne in niso vprašljive.

Analiza starejših raziskav o preferencah do okolice, zadovoljstva s stanovanjem in navezanosti na kraj so pokazale, da lahko značilnosti okolja in lokacije doma, na katere so ljudje pozorni, razdelimo v štiri skupine: (a) fizično okolje, (b) socialno okolje, (c) dostopnost lokalnih javnih in zasebnih storitev ter (d) lokacija in prevoz v širšem kontekstu. Faktorsko analizo šestnajstih vprašanj o preferencah v danski anketi lahko interpretiramo 
tako, da šest različnih dejavnikov vpliva na to, kako ljudje izbirajo lokacijo in okolico svojega doma. Ti so: (a) izogibanje socialnim tegobam, (b) dobri pogoji za ustvarjanje družine, (c) socialna homogenost, (d) bližina narave in mirne okolice, (e) bližina socialnih mrež ter (f) bližina mestnega utripa in prevoza. Socialno okolje je tako razdeljeno na tri vidike: socialne tegobe, socialna homogenost in prostorska bližina posameznikove socialne mreže. Zanimivo je to, da preference do izogibanja soseskam s socialnimi problemi in kriminalom niso zelo povezane s preferencami do socialne homogenosti; $\mathrm{z}$ drugimi besedami, z življenjem $\mathrm{v}$ soseski z malo narodnostnimi manjšinami in kateri prebivalci niso preveč drugačni. Teh različnih preferenc torej nimajo isti ljudje, čeprav danski mediji socialne probleme in kriminal pogosto povezujejo $\mathrm{z}$ večetničnimi soseskami. To bi lahko pomenilo, da so preference do socialne homogenosti v soseskah bolj povezane s političnimi stališči in mogoče s statusom.

Raziskava nakazuje, da na Danskem prebivalci v splošnem pripisujejo večjo težo izogibanju socialnim tegobam, bližini narave ter bližini sorodnikov in prijateljev. Vendar se preference močno razlikujejo med različnimi podskupinami prebivalstva. Prispevek temelji na Ærøvi (2002) teoriji izbire stanovanja, v kateri so opredeljene te tri skupine:

- tiste, ki ne izbirajo (predsodobna modalnost);

- tiste, ki izbirajo (sodobna modalnost);

- tiste, ki nenehno izbirajo (pozna sodobna modalnost).

Osebe iz prve skupine so vnaprej izbrale specifično lokacijo z določno socialno, kulturno in fizično vsebino, ker so navezane nanjo. Take osebe bodo izrazile preference, ki se ujemajo $\mathrm{z}$ že obstoječo vsebino, ali pa ne bodo imele nobenih posebnih preferenc. Tretja skupina nima posebno močnih preferenc do doma in njegove okolice, temveč bolj do njegove lokacije in dostopnosti storitev, prevoza in kulture. Za te ljudi je dom samo eden od krajev, v katerih počutijo doma. Enako domače se počutijo v krajih, v katere potujejo ali v njih preživljajo dopust. Dom je kraj, na katerem se spočijejo in spijo, medtem ko pravo življenje poteka drugje. Za drugo skupino je dom zelo pomemben kot temelj družinskega življenja in zato omogoča, da je vsakdanje življenje prijetno in funkcionalno. Tem osebam sta dom in njegova okolica zelo pomembna, zlasti če imajo otroke, kar se izraža v njihovih preferencah. Ta skupina ima veliko število močnih preferenc.

Empirični dokazi v tem prispevku potrjujejo Ærøvo teorijo. Najprej se je izkazalo, da imajo nekateri anketiranci močne preference do številnih različnih lastnosti okolice in lokacije doma, medtem ko jih imajo drugi zelo malo. Pokazalo se je, da so preference, ki jih lahko povežemo s prvo skupino oziroma z dejavnikom »bližina socialnih mrež« (bližina sorodnikov in prijateljev ter kraja odraščanja), le malo povezane z drugimi preferencami, kar pomeni, da imajo ljudje s temi preferencami redko druge preference. Pokazalo se je tudi, da imajo ljudje, ki imajo preference, ki jih lahko povežemo z zadnjo skupino (življenje blizu mestnega utripa in prometne infrastrukture), redko druge preference. Večina drugih preferenc pa se je pogosto pojavila skupaj, kar kaže na to, da ima druga skupina veliko število različnih preferenc.

Ta raziskava ponazarja, kako se preference do okolice in lokacije doma v življenju posameznika pričakovano spremenijo. Prevladujoči dejavnik pri mladih je bližina mestnega utripa in prevoza; ta preferenca se postopoma manjša s starostjo in ko si najdejo življenjskega sopotnika. Te preference popolnoma izginejo, ko ljudje dobijo otroke. Bližina socialnih mrež je tudi zelo pomembna za mlade ljudi, ne pa za družine $z$ otroki in starejše, kar je nekoliko presenetljivo. Nasprotne spremembe so značilne za preference do narave, ki so zelo nizke med mladimi in zelo visoke med starejšimi. Preference do dobrih pogojev za otroke so (pričakovano) zelo pomembne za družine $\mathrm{z}$ otroki in tudi za nekatere mlade pare, ki pričakujejo otroke. Za družine z otroki je tudi zelo pomembno, da se izognejo socialnim tegobam v soseski, čeprav to ni pomembno za mlade samske osebe. Preference do socialne homogenosti v soseski so zelo pomembne za samske osebe, stareǰ̌e od šestdeset let, in do neke mere za starejše pare.

Obstaja nekaj zelo pričakovanih povezav med lokacijskimi preferencami do življenja v velikem mestu, podeželskem mestu ali na podeželju ter preferencami do okolice in lokacije doma, obstaja pa tudi nekaj nepričakovanih povezav. Pričakovano so preference do mestnega življenja veliko pogostejše $\mathrm{v}$ mestih kot $\mathrm{v}$ vaseh in na podeželju, pri bližini narave pa velja prav obratno. Mogoče je manj pričakovano dejstvo, da so socialne mreže najpomembnejše $\mathrm{v}$ predmestjih, podeželskih mestih in vaseh, ne pa na podeželju. Preference do izogibanja socialnim tegobam so najpomembnejše na gosto poseljenih območjih zunaj mestnih jeder in v predmestjih, kar lahko pojasnimo z dejstvom, da so tam socialni problemi in kriminal najpogostejši. Želja po socialni homogenosti je najpogosteje povezana s preferencami do življenja $\mathrm{v}$ predmestjih.

Hans Skifter Andersen

Danish Building Research Institute at the University of Aalborg, Hørsholm, Danska

E-pošta: hsa@sbi.dk

\section{Literatura in viri}

Ærø, T. (2002): Boligpræferencer, boligvalg \& livsstil. Doktorska disertacija. Hørsholm, Statens Byggeforskningsinstitut, Oddelek za stanovanjske in urbane raziskave.

Ærø, T. (2006): Residential choice from a lifestyle perspec- 
tive. Housing, Theory and Society, 23(2), str. 109-130. DOI: $10.1080 / 14036090600773139$

Artle, R., in Varaiya, P. (1978): Life cycle consumption and homeownership. Journal of Economic Theory, 18(1), str. 38-58. DOI: 10.1016/0022-0531(78)90041-8

Basolo, V., in Strong, D. (2002): Understanding the neighbourhood: From residents' perception and needs to action. Housing Policy Debate, 13(1), str. 83-105.

Carp, F., Zawadski, R., in Shokron, H. (1976): Dimensions of urban environmental quality. Environment and Behaviour, 8(2), str. 239265. DOI: $10.1177 / 001391657682004$

Clapham, D. (2005): The meaning of housing: A pathways approach. Bristol, Policy Press.

Clark, W. A. V., in Onaka, J. L. (1983): Life cycle and housing adjustment as explanations of residential mobility. Urban Studies, 20(1), str. 47-57.

Coolen, H., in Hoekstra, J. (2001): Values as determinants of preferences for housing attributes. Journal of Housing and the Built Environment, 16(3-4), str. 285-306. DOI: 10.1023/A:1012587323814

Costa Pinho, T. (2000): Residential contexts of social exclusion: Images and identities. Prispevek je bil predstavljen na mednarodni raziskovalni konferenci Inštituta za stanovanjske raziskave, Univerza Uppsala, pod pokroviteljstvom Evropske mreže za stanovanjske raziskave, ki je potekala od 26. do 30. junija v mestu Gävle na Švedskem. Tipkopis.

Cuba, L., in Hummon, D. M. (1993): A place to call home: Identification with dwelling, community and region. The Sociological Quarterly, 34(1), str. 111-131. DOI: 10.1111/j.1533-8525.1993.tb00133.x

Floor, H., in Van Kempen, R. (1997): Analysing housing preferences with decision plan nets. Scandinavian Housing and Planning Research, 14(1), str. 27-42.

Franscescato, G., Wiedemann, S., in Anderson, J. R. (1987): Residential satisfaction. V: Van Vliet, W., idr. (ur.): Housing and neighbourhoods: Theoretical and empirical contributions, str. 43-58. New York, Greenwood Press.

Galster, G., Hayes, C., in Johnston, J. (2002): Identifying robust, parsimonious indicators of neighbourhood quality of life. Journal of Planning Education and Research, 24(3), str. 265-280. DOI: $10.1177 / 0739456 \times 04267717$

Gruber, K. J., in Shelton, G. G. (1986): Assessment of neighbourhood satisfaction by residents of three housing types. Social Indicators Research, 19(3), str. 303-315. DOI: 10.1007/BF00300363

Hidalgo, M. C., in Hernández, B. (2001): Place attachment: Conceptual and empirical questions. Journal of Environmental Psychology, 21(3), str. 273-281. DOI: 10.1006/jevp.2001.0221

Howell, F. M., in Freese, W. (1983): Size of place, residential preferences and the life cycle: How people come to like where they live. American Sociological Review, 48(4), str. 569-580. DOI: $10.2307 / 2117723$

Johnston, R. J. (1973): Spatial patterns in suburban evaluations. Environment and Planning A, 5(3), str. 385-395. DOI: 10.1068/a050385

Kauko, T. (2006): What makes a location attractive for the housing consumer? Preliminary findings from metropolitan Helsinki and
Randstad Holland using the analytical hierarchy process. Journal of Housing and the Built Environment, 21(2), str. 159-176. DOI: 10.1007/s10901-006-9040-y

Mesch, G. S., in Manor, O. (1998): Social ties, environmental perception and local attachment. Environment and Behaviour, 30(4), str. 504-519. DOI: 10.1177/001391659803000405

Molin, E. J. E., Oppewal, H., in Timmermanns, H. J. P. (2001): Analysing heterogeneity in conjoint estimates of residential preferences. Journal of Housing and the Built Environment, 16(3-4), str. 267-284. DOI: 10.1023/A:1012539415696

Mulder, C. H. (2007): The family context and residential choice: A challenge for new research. Population, Space and Place, 13(4), str. 265-278. DOI: 10.1002/psp.456

Parkes, A., Kearns, A., in Atkinson, R. (2002): What makes people dissatisfied with their neighbourhoods? Urban Studies, 39(13), str. 2413-2438. DOI: 10.1080/0042098022000027031

Rossi P. H. (1955): Why families move. Glencoe, IL, Free Press.

Sirgy, M. J., Grzeeskowial, S., in Su, C. (2005): Explaining housing preferences and choice: The role of self-congruity and functional congruity. Journal of Housing and the Built Environment, 20(4), str. 329-347. DOI: 10.1007/s10901-005-9020-7

Skifter Andersen, H. (2008): Why do residents want to leave deprived neighbourhoods? The importance of residents' subjective evaluations of their neighbourhood and its reputation. Journal of Housing and the Built Environment, 23(2), str. 79-101. DOI: 10.1007/ s10901-008-9109-x

Skifter Andersen, H. (v tisku): Explanations for long-distance counter-urban migration into fringe areas in Denmark. Population, Space and Place.

Skifter Andersen, H., in Bonke, J. (1980): Boligsektorens fordelingsmæssige virkninger. Copehagen, Lavindkomstkommisionen.

Timmermans, H., Molin, E., in Van Noortvijk, L. (1994): Housing choice processes: Stated versus revealed modelling approaches. Journal of Housing and the Built Environment, 9(3), str. 215-227. DOI: 10.1007/BF02496997

Vorel, J., in Maier, K. (2007): Learning the public preferences for living environment characteristics: the experimental approach. Prispevek je bil predstavljen na konferenci, z naslovom REAL CORP 007, ki je potekala od 20. do 23. maja na Dunaju v Avstriji. Tipkopis.

Wheaton, W. C. (1985): Life-cycle theory, inflation, and the demand for housing. Journal of Urban Economics 18(2), str. 161-179. DOI: 10.1016/0094-1190(85)90014-2 